\title{
"The effect of announcement as the host of XVIII Asian Games on the Indonesian stock market"
}

Andreas Andreas (D https://orcid.org/0000-0002-6196-2663

AUTHORS

Tatang Ary Gumanti iD https://orcid.org/0000-0003-1751-2590

Uliya Nurjannah

Intan Nurul Awwaliyah

Andreas Andreas, Tatang Ary Gumanti, Uliya Nurjannah and Intan Nurul

ARTICLE INFO

Awwaliyah (2020). The effect of announcement as the host of XVIII Asian Games on the Indonesian stock market. Investment Management and Financial Innovations, 17(1), 109-118. doi:10.21511/imfi.17(1).2020.10

DOI http://dx.doi.org/10.21511/imfi.17(1).2020.10

RELEASED ON

Wednesday, 04 March 2020

RECEIVED ON

Thursday, 16 January 2020

ACCEPTED ON

Tuesday, 11 February 2020

(cc) EY

LICENSE

This work is licensed under a Creative Commons Attribution 4.0 International License

JOURNAL

"Investment Management and Financial Innovations"

ISSN PRINT $1810-4967$

ISSN ONLINE $1812-9358$

PUBLISHER

LLC "Consulting Publishing Company "Business Perspectives"

FOUNDER

LLC "Consulting Publishing Company "Business Perspectives”

NUMBER OF REFERENCES

21
NUMBER OF FIGURES

1
ニニ:

NUMBER OF TABLES

7

(C) The author(s) 2023. This publication is an open access article. 


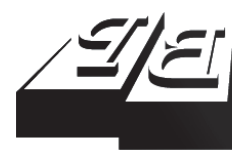

\section{BUSINESS PERSPECTIVES}

(O)

LLC "CPC "Business Perspectives" Hryhorii Skovoroda lane, 10 Sumy, 40022, Ukraine www.businessperspectives.org

Received on: $16^{\text {th }}$ of January, 2020 Accepted on: $11^{\text {th }}$ of February, 2020 Published on: $4^{\text {th }}$ of March, 2020

(c) Andreas, Tatang Ary Gumanti, Uliya Nurjannah, Intan Nurul Awwaliyah, 2020

Andreas, Associate Professor, Faculty of Economics, Universitas Riau, Indonesia.

Tatang Ary Gumanti, Ph.D. Professor, Faculty of Economics, University of Bhayangkara Jakarta Raya, Jl Perjuangan Bekasi West Java, Indonesia.

Uliya Nurjannah, Assistant Researcher, Faculty of Economics and Business, University of Jember, Indonesia.

Intan Nurul Awwaliyah, Ph.D., Senior Lecturer, Faculty of Economics and Business, University of Jember Indonesia.
Andreas (Indonesia), Tatang Ary Gumanti (Indonesia), Uliya Nurjannah (Indonesia), Intan Nurul Awwaliyah (Indonesia)

\section{THE EFFECT OF ANNOUNCEMENT AS THE HOST OF XVIII ASIAN GAMES ON THE INDONESIAN STOCK MARKET}

\begin{abstract}
In 2014, Indonesia was announced to be the host the 2018 XVIII Asian Games, the biggest sports event in Asia. This announcement is expected to positively impact the country's economy and investors as there would be thousands of spectators from both the country and overseas. A direct impact of the event is that Indonesia would prepare the entire venue. This study examines whether the capital market participants react to the announcement. For this purpose it tests a total of 25 companies in the infrastructure, utility, and transportation sectors listed on the Indonesia Stock Exchange. A standard event study methodology is employed to examine the existence of abnormal returns around the event. The results show the abnormal returns on two days before and two days after the announcement. However, overall, there are no significant abnormal returns before and after the announcement. The study does not find a significant difference of abnormal returns before and after the announcement. Besides, there was no difference in trading volume activity before and after the announcement as the host of the XVIII Asian Games. In summary, the capital market participants do not consider the event to be a significant issue that determines their investment decision in the capital market.
\end{abstract}

\section{Keywords}

event study, abnormal returns, market reaction, Asian Games

\section{JEL Classification $\quad$ G11, G12, G14}

\section{INTRODUCTION}

On July 25, 2014, the Olympic Council of Asia (OCA) appointed Indonesia to host the XVIII Asia's biggest sport event, the 2018 Asian Games, replacing Vietnam that withdrew because of infrastructure and economic unpreparedness. The Asian Games are expected to the boost country's economy and do an honor to the host country, as well as to be one of the events that the investors cannot ignore, in particular in the stock market. If the event has significant added value to the economy, the investors would react positively.

According to the efficient market hypothesis (Fama, 1970), the market will react rapidly to the information. Every event or information can be considered important, to which the market participants can react in predicting its impact. The reaction is reflected in the form of abnormal returns. The reaction on the capital market can also be assessed based on trading volume activity (comparison of the number of shares traded)

The infrastructure, utilities, and transportation sectors play an important role in the smooth running of the Asian Games. The appointment of Indonesia as the host requires several projects related to infrastructure and utilities that are being or will be built and must be completed 
immediately before the event. Some of them are the construction of Kemayoran Athletes House, which consists of ten towers containing 7,426 units, and the renovation of Bung Karno Gelora related to the main stadium, training facilities, swimming stadium, Istora Senayan renovation, and various supporting facilities. The transportation sector also plays a role in providing transportation-related services for supporters and sports contingents. The share prices of infrastructure sector companies also experienced a high increase of $21.81 \%$, compared to several other sectors.

On July 25, 2014, the Jakarta Composite Index showed 5,088.80, while on the first trading day after the Indonesian Stock Exchange closed, which was on August 4, 2014, the Composite Index increased by 30.45 to $5,119.25$, or $0.60 \%$. On July 25,2014 , the infrastructure, utilities, and transportation index showed $1,137.5$ and increased by 21.55 to $1,159.05$, or $1.89 \%$. The data illustrate that on the date around the event, the combined stock index and sectoral index responded positively to the announcement of the host of the XVIII Asian Games.

The appointment of Indonesia as the host of the Asian Games was for the first time after 52 years of waiting. Indonesia was once the host of the IV Asian Games in 1962. Long time after the first appointment of Indonesia as the host made this research interesting to do. Did investors respond to the good news by having shown the abnormal returns and trading activity on the date around the announcement of the host of the XVIII Asian Games?

Referring to the earlier description and under the efficient market hypothesis suggesting that stock market will react instantly to the new information, this study examines the stock market reaction to the announcement Indonesia as the host of the XVIII Asian Games using the event study approach. Basically, reaction was tested based on two aspects, namely abnormal returns and stock trading volume. Previous research on the stock market reaction to an event found different results. Spais and Filis (2006), Benkraiem et al. (2009), Scholtens and Peenstra (2009), Mirman and Sharma (2010), Dick and Wang (2010) found that an event had a significant impact on abnormal returns. Spais and Filis (2006), Benkraiem et al. (2009), and Scholtens and Peenstra (2009) also found that an event had a significant influence on trading volume. In Indonesia, Suryanto (2015) found no difference of the average abnormal returns, while Purnasari (2015) found a significant difference around the event.

Using a sample of 25 companies in the infrastructure, utility, and transportation sectors, and employing the standard event study methodology, the study does not find strong evidence of abnormal returns around the event. Besides, there is no significant difference of trading activity before and after the event. Thus, market participants do not react abnormally to the announcement of the event.

\section{LITERATURE REVIEW AND RESEARCH HYPOTHESES}

\subsection{Theoretical and empirical studies}

Event study is often related to efficient markets. Fama (1991) refers to the semi-strong form of market efficiency hypothesis as an event study. Bodie, Kane, and Marcus (2018) describe an event study as a method of financial research to examine the impact of an event on the stock price movement. Konchitchki and O'Leary (2011) state that event studies are based on efficient capital markets and the idea that the price of securities is reflected by the quality of available information. This event could be in the form of microlevel such as corporate actions, while the macrolevel could be any event that affects all or specific industries. Sorescu, Warren, and Ertekin (2017) assert that the event study aims to assess the extent to which investors can gain excess or abnormal stock returns from an event that brings new informational content.

Event studies are used to examine the informational content based on the presence of information or announcements, and to test the efficiency 
of semi-strong market efficiency hypothesis. If an announcement has information content, the market will immediately react. The market reaction can be seen from the existence of abnormal returns as a measure of price changes.

Some studies have tested the effect of an event or information coming from outside the company. For example, Spailis and Filis (2006) found the significant abnormal returns and high changes in trading volume of the sponsor company shares during the Olympic Games. Benkraiem, Louhichi, and Marques (2009) and Scholtens and Peenstra (2009) found that soccer club sports results affect the abnormal returns and trading volume around the match date. The market responded negatively to a defeat, and it responded positively to a victory. Mirman and Sharma (2010) and Dick and Wang (2010) found that the Olympic Games announcement had a significant effect on returns and abnormal returns. Positive and negative impacts depend on when the Olympic Games are held, where the market responded positively to summer but responded negatively to winter. Asteriou et al. (2013) found that the 2012 Olympic Games in London affected several stock prices on several indices positively, but had a significant negative impact on share prices in the oil and gas industry. Abuzayed (2013) found that the announcement of the 2022 World Cup affected the abnormal returns, especially in the service sector, but found no significant volatility effects on the Qatar capital market. Overall, the effect of the events is inconclusive. That is, the same event affects the stock price of certain industry, but it does not affect another type of industry.

Research on event studies has also been carried out in Indonesia. For example, Suryanto (2015) found that investment grade announcements had no significant effect on differences in average abnormal returns, but there were significant abnormal returns before the event. Purnasari (2015) found that regulations prohibiting the export of raw materials had a significant effect on abnormal returns when official regulations were implemented, but the trading volume did not differ significantly.

Various kinds of information and events will have different impacts on capital market reactions. Spais and Fillis (2006), Benkraiem et al. (2009),
Scholtens and Peenstra (2009), Mirman and Sharma (2010), Asteriou, Samitas, and Kenourgios (2013), Purnasari (2015), and Suryanto (2015) found that an event had an impact on returns and abnormal returns, while Dick and Wang (2010) did not find any significant abnormal returns due to an event. Spais and Fillis (2006), Benkariem et al. (2009), Scholtens and Peenstra (2009), and Purnasari (2015) found that an event also affected the trading volume around the event. That is, the reaction obtained can be either positive or negative.

\subsection{Research hypotheses}

Sorescu et al. (2017) assert that an event study aims to assess the extent to which investors can gain excess or abnormal stock returns from an event that brings new information content. Spais and Fillis (2006), Benkaraiem et al. (2009) and Scholtens and Peenstra (2009) found that sports match results affect the abnormal returns around the match date. The market responded to the announcement of the winning country positively, while it responded to the news of the defeat negatively. Mirman and Sharma (2010) found that the announcement of the host country of the Olympic Games had a significant positive effect on the abnormal returns of S\&P Global 1200 Index shares around the event date. However, Dick and Wang (2010) found no significant returns and abnormal returns around the Olympic Games host country announcement date.

Spais and Fillis (2006) found that the announcement of the Olympic Games host country affected the changes in the company's stock trading volume during the game. Benkaraiem et al. (2009) reported that the results of football matches in the European countries influence the volume of stock trading around the event. Scholtens and Peenstra (2009) also documented a significant positive stock trading volume when the winner of the match was announced, but there was a negative change in trading volume when the losing team was announced.

Spais and Fillis (2006), Benkaraiem et al. (2009), Scholtens and Peenstra (2009), Mirman and Sharma (2010) found that an event affected the abnormal returns. However, Dick and Wang 
(2010) found no abnormal returns. Spais and Fillis (2006), Benkariem et al. (2009), and Scholtens and Peenstra (2009) also found that an event affected the stock trading volume. Previous studies have detected that information or event can have a different effect on abnormal returns and stock trading volume on the capital market. Based on the conceptual framework and the description above, the hypotheses in this study are as follows:

H1: There are significant abnormal stock returns of the companies in infrastructure, utilities, and transportation sectors listed on the Indonesia Stock Exchange before and after the announcement as the host of the XVIII Asian Games.

H2: There are significant different abnormal stock returns of the companies in infrastructure, utilities, and transportation sectors listed on the Indonesia Stock Exchange before and after the announcement as the host of the XVIII Asian Games.

H3: There is a significant difference in the trading activity of the companies in infrastructure, utilities, and transportation sectors listed on the Indonesia Stock Exchange before and after the announcement as the host of the XVIII Asian Games.

\section{METHODS}

This study uses an event study approach. The data were collected from the Indonesia Stock Exchange website. The establishment of the Asian
Games was announced on July 25, 2014. The period used is ten trading days as shown in Figure 1 , where the period is five days before the announcement of the Asian Games (pre-event) and five days after the announcement of the Asian Games (post-event).

The study was carried out before the event, which was July 18, 2014, continued from July 21, 2014 till July 24,2014 , and the current period of the event, which was July 25, 2014, and from August 4, 2014 till August 8, 2014 as the period after the event. On July 19, 2014 and July 20, 2014 there were weekend holidays, and from July 26, 2014 till August 3, 2014, there was Idul Fitri holiday so that the Indonesian Stock Exchange was closed. These dates are not included in the observation period because there are no trading transactions.

The research population is 47 companies in the infrastructure, utilities, and transportation sectors listed on the Indonesia Stock Exchange. The sample is determined using the purposive sampling method by applying two criteria. Firstly, the company does not have corporate action at the date of observation, because companies that do corporate action will usually affect the changes in stock prices. Secondly, the company stocks are actively traded around the date of the event, because companies that are actively traded are considered attractive for investors. Total sample consists of 25 companies.

Abnormal return is calculated as the difference between actual return and expected return measured daily. Individual actual stock return is calculated using the following formula:

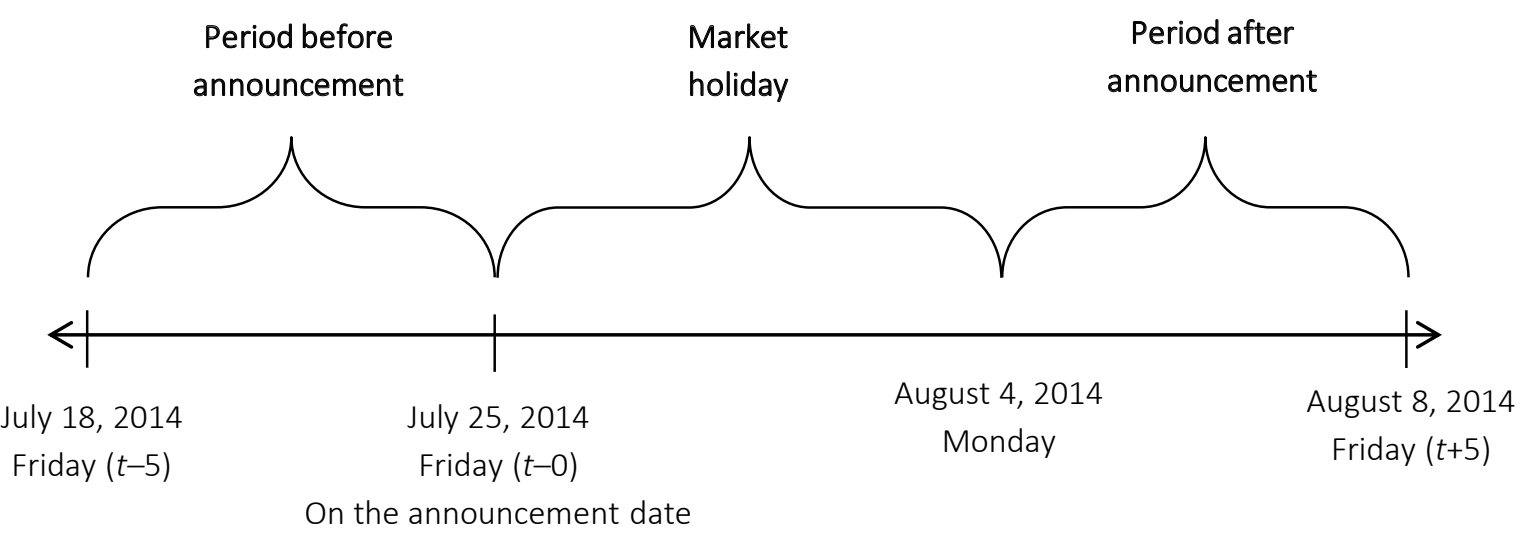

Figure 1. Event study window 


$$
R_{i t}=\ln \left(\frac{P_{i t}}{P_{i t-1}}\right),
$$

where $R_{i t}$ is return of stock $i$ at time $t, P_{i t}$ is closing price of stock $i$ at time $t$, and $P_{i t-1}$ is closing price of stock $i$ at time $t-1$. Expected returns are calculated using the market-adjusted model to calculate the expected returns. This model shows that the best estimator in estimating the returns is the market return (Brown \& Warner, 1985). Abnormal returns are calculated using the following equation:

$$
A R_{i t}=R_{i t}-R_{m}
$$

Trading volume activity (TVA) is the number of shares traded during one period compared to the number of shares outstanding during the study period. Trading volume activity is calculated using the following formula (Foster, 1986):

$$
T V A_{i t}=\frac{\sum_{\text {traded of company } i}^{\text {number of shares }}}{\sum_{\text {outstanding of company } i}^{\text {number of shares }}} .
$$

\section{RESULTS}

\subsection{Description of research variables}

The study population is all companies included in infrastructure, utilities, and transportation sector from July 2014 till August 2014, totaling 47 com-

\begin{tabular}{|c|c|c|}
\hline No & Description & $\begin{array}{l}\text { Number } \\
\text { of firms }\end{array}$ \\
\hline 1 & $\begin{array}{l}\text { Number of infrastructure, utilities, and } \\
\text { transportation sector companies listed on the } \\
\text { Indonesia Stock Exchange from July till August } \\
2014\end{array}$ & 47 \\
\hline 2 & $\begin{array}{l}\text { Companies that carry out corporate activity by } \\
\text { July } 18,2014 \text { till August } 8,2014\end{array}$ & 19 \\
\hline 3 & $\begin{array}{l}\text { Company that did not actively trade from July } 18 \text {, } \\
2014 \text { till August } 8,2014\end{array}$ & 3 \\
\hline \multicolumn{2}{|c|}{ Final number of research samples } & 25 \\
\hline
\end{tabular}
panies. Table 1 shows the sample selection process.

Table 1. Sample selection process

Forty-seven (47) companies were included in the infrastructure, utilities and transportation sectors, but 25 companies have met the criteria to be used as research samples. The sample consists of three energy subsector companies, two toll road subsector companies, airports, ports and the like, four telecommunications subsector companies, 14 transportation subsector companies, and two non-building construction subsector companies. Table 2 presents a summary of the number of samples in each subsector.

Table 2. Number of samples in the subsectors

\begin{tabular}{c|l|c|c|c}
\hline No. & Subsector & $\begin{array}{c}\text { Number of } \\
\text { populations }\end{array}$ & $\begin{array}{c}\text { Number } \\
\text { of } \\
\text { samples }\end{array}$ & $\begin{array}{c}\% \text { from } \\
\text { total } \\
\text { sample }\end{array}$ \\
\hline 1 & Energy & 3 & 3 & $12 \%$ \\
\hline 2 & $\begin{array}{l}\text { Toll roads, airports, } \\
\text { ports and the like }\end{array}$ & 3 & 2 & $8 \%$ \\
\hline 3 & Telecommunication & 5 & 4 & $16 \%$ \\
\hline 4 & Transportation & 29 & 14 & $56 \%$ \\
\hline 5 & Non-building & 7 & 2 & $8 \%$ \\
\hline Total & construction & 7 & 25 & $100 \%$ \\
\hline
\end{tabular}

Table 3 presents the statistical description of abnormal returns data. It can be seen that the mean abnormal returns fluctuate. The mean abnormal returns before the announcement tends to increase. However, on the eve of the announcement, that is, $\mathrm{h}-3, \mathrm{~h}-2$, and $\mathrm{h}-1$, abnormal returns increased. On the AR-day after the announcement, namely $\mathrm{h}+1$ and $\mathrm{h}+2$, the abnormal returns decrease, but on $\mathrm{h}+3$ and $\mathrm{h}+4$ after the announcement, the abnormal returns show an increase and are positive. This indicates that investors are starting to absorb information about the announcement of the host of the Asian Games. Investors responded positively to the news with a marked increase in abnormal returns. On $h+5$ after the announcement of the host, the abnormal returns decrease and are negative. This indicates that investors are starting to lose euphoria for the appointment of the Asian Games host and are likely to suffer losses.

Table 4 presents a complete statistical description of the trading volume activity data. In Table 4 , for the five days before the announcement of TVA, the highest occurred on July 22, 2014, or h-3 announcements, which amounted to $1.57 \%$. Meanwhile, the lowest mean trading volume of activity on July 23, 2014, or d-2 announcements was $1.03 \%$. The highest TVA value for the five days after the announcement occurred on August 6, 2014 , or $\mathrm{h}+3$ announcements and is equal to $2.55 \%$. 
Table 3. Statistical description of abnormal returns data

\begin{tabular}{|c|c|c|c|c|c|c|}
\hline Description & Day & Mean & Median & Min & Max & Standard deviation \\
\hline \multirow{5}{*}{ Before } & $h-5$ & -0.0004 & -0.0040 & -0.0300 & 0.0500 & 0.0195 \\
\hline & $h-4$ & -0.0037 & -0.0070 & -0.0400 & 0.0600 & 0.0191 \\
\hline & $h-3$ & 0.0010 & -0.0020 & -0.0300 & 0.0800 & 0.0221 \\
\hline & $h-2$ & 0.0086 & 0,0060 & -0.0100 & 0.0400 & 0.0127 \\
\hline & $h-1$ & 0.0107 & 0,0005 & -0.0200 & 0.1000 & 0.0262 \\
\hline Event date & ho & 0.0042 & 0.0020 & -0.0200 & 0.0600 & 0.0151 \\
\hline \multirow{5}{*}{ After } & $h+1$ & -0.0077 & -0.0200 & -0.0500 & 0.0900 & 0.0359 \\
\hline & $h+2$ & -0.0044 & -0.0010 & -0.0500 & 0.0600 & 0.0199 \\
\hline & $h+3$ & 0.0267 & 0.0100 & -0.0400 & 0.3000 & 0.0731 \\
\hline & $h+4$ & 0.0027 & 0.0020 & -0.0700 & 0.0500 & 0.0237 \\
\hline & $h+5$ & -0.0029 & -0.0030 & -0.0300 & 0.0300 & 0.0135 \\
\hline Mean AR before & $(h-5-h-1)$ & 0.0032 & 0.0020 & -0.0080 & 0.0400 & 0.0099 \\
\hline Mean AR after & $(h+1-h+5)$ & 0.0023 & 0.0007 & -0.0300 & 0.0600 & 0.0156 \\
\hline
\end{tabular}

Meanwhile, the lowest mean was on August 4 and August 8,2014 , or $\mathrm{h}+1$ and $\mathrm{h}-5$ announcements, namely $1.14 \%$. TVA trends on the first day after the announcement decreased. However, at $h+2$ and $h+3$ after the announcement of trading, the activity volume has increased. This indicates that the increase in TVA occurred on the second and third days after the announcement.

The first hypothesis in this study is that there are abnormal returns before and after the announcement of the host of the XVIII Asian Games. Hypothesis was tested using one-sample $t$-test on $\mathrm{h}-2$ and $\mathrm{h}+4$ and Wilcoxon one-sample test on other days. Table 5 presents a summary of the results.

The test results show that on $p-4$ and $p-2$ before the announcement of the host, each $p$-value is $0.099(p<10 \%)$ and $0.003(p<1 \%)$. That is, on $\mathrm{h}-4$ and $\mathrm{h}-2$ before the announcement, there are significant abnormal returns. In line with the test results before the announcement, on $\mathrm{h}+3$ and $\mathrm{h}+5$ after the announcement, significant abnormal returns were found. That is, on $\mathrm{h}+3$ and $\mathrm{h}+5$ after the announcement, there are significant abnormal returns.

Based on the description above, it can be seen that before the announcement, two days showed significant abnormal returns, namely $\mathrm{d}-4$ and d-2. After the announcement, two days, namely $h+3$ and $h+5$, showed significant abnormal returns. Meanwhile, no significant abnormal returns were found on other seven days. Thus, it can be concluded that the alternative hypothesis, which states that there are abnormal returns on the day before and after the announcement of the host of the XVIII Asian Games, is rejected. That is, there is insufficient evidence of abnormal returns on the days before and after the announcement.

Table 4. Statistical description of trading volume activity data

\begin{tabular}{|c|c|c|c|c|c|c|}
\hline Description & Day & Mean & Median & Min & Max & Standard deviation \\
\hline \multirow{5}{*}{ Before } & $h-5$ & 0.0110 & 0.0024 & 4.00.E-05 & 0.1100 & 0.0254 \\
\hline & $h-4$ & 0.0106 & 0.0042 & 5.00.E-07 & 0.1000 & 0.0214 \\
\hline & $h-3$ & 0.0157 & 0.0071 & 1.80.E-06 & 0.1600 & 0.0322 \\
\hline & $h-2$ & 0.0103 & 0.0044 & 5.90.E-05 & 0.0820 & 0.0185 \\
\hline & $h-1$ & 0.0129 & 0.0047 & 2.50.E-07 & 0.0960 & 0.0226 \\
\hline Event date & ho & 0.0153 & 0.0040 & 4.10.E-05 & 0.1300 & 0.0287 \\
\hline \multirow{5}{*}{ After } & $h+1$ & 0.0114 & 0.0028 & 4.80.E-07 & 0.0810 & 0.0196 \\
\hline & $h+2$ & 0.0115 & 0.0037 & 2.50.E-07 & 0.0870 & 0.0214 \\
\hline & $h+3$ & 0.0255 & 0.0052 & 2.50.E-07 & 0.2900 & 0.0610 \\
\hline & $h+4$ & 0.0191 & 0.0068 & 2.50.E-07 & 0.2100 & 0.0434 \\
\hline & $h+5$ & 0.0114 & 0.0045 & 2.50.E-07 & 0.1300 & 0.0272 \\
\hline Mean AR before & $(h-5-h-1)$ & 0.0122 & 0.0061 & 1.80.E-04 & 0.1100 & 0.0234 \\
\hline Mean AR after & $(h+1-h+5)$ & 0.0158 & 0.0053 & 1.10.E-06 & 0.1100 & 0.0287 \\
\hline
\end{tabular}


Table 5. Summary of first hypothesis testing results

\begin{tabular}{|c|c|c|c|c|c|}
\hline Period & Mean & $p$-value & Median & $p$-value & Conclusion \\
\hline$h-5$ & -0.0004 & 0.918 & -0.0040 & 0.396 & No AR \\
\hline$h-4$ & -0.0037 & 0.348 & -0.0070 & $0.099^{*}$ & There is AR \\
\hline$h-3$ & 0.0010 & 0.824 & -0.0020 & 0.705 & No AR \\
\hline$h-2$ & 0.0086 & $0.003^{* * *}$ & 0.0060 & 0.004 & There is AR \\
\hline$h-1$ & 0.0107 & 0.053 & 0.0005 & 0.256 & No AR \\
\hline ho & 0.0042 & 0.173 & 0.0020 & 0.219 & No AR \\
\hline$h+1$ & -0.0077 & 0.296 & -0.0200 & 0.137 & No $A R$ \\
\hline$h+2$ & -0.0044 & 0.284 & -0.0010 & 0.182 & No AR \\
\hline$h+3$ & 0.0267 & 0.081 & 0.0100 & $0.087^{*}$ & There is AR \\
\hline$h+4$ & 0.0027 & 0.578 & 0.0020 & 0.345 & No AR \\
\hline$h+5$ & -0.0029 & 0.302 & -0.0030 & $0.049^{* *}$ & There is $A R$ \\
\hline$(h-5-h-1)$ & 0.0032 & 0.120 & 0.0020 & 0.220 & No AR \\
\hline$(h+1-h+5)$ & 0.0023 & 0.470 & 0.0007 & 0.746 & No AR \\
\hline
\end{tabular}

Note: ${ }^{* * *},{ }^{* *},{ }^{*}$ significant at $1 \%, 5 \%$, and $10 \%$, respectively. The bold print indicates that the hypothesis testing is based on the results of the data distribution pattern. If the data are normally distributed, then the test is based on one-sample $t$-test, but if the data distribution is abnormal, then the Wilcoxon test is used. AR is abnormal returns.

The second hypothesis is tested to find a difference in abnormal returns before and after the announcement. Because data distribution patterns indicate that the data are not normally distributed, hypothesis testing is based on the Wilcoxon test.

Table 6 presents a summary of the results of the second hypothesis testing, results showed that before the announcement on $\mathrm{h}-4$, $\mathrm{h}$ had a medi- an increase of $0.9 \%$ and a mean increase of $0.79 \%$ $(p<10)$. This means that there are significant abnormal return differences before and after the announcement as the host of the XVIII Asian Games.

Table 6 also illustrates that on two days after the announcement, namely $\mathrm{h}+1$ and $\mathrm{h}+2$, there was a decrease in median by $2.2 \%$ and $0.3 \%$, respectively. Mean abnormal return on $\mathrm{h}+1$ and $\mathrm{h}+2$ also

Table 6. Summary of second hypothesis testing results

\begin{tabular}{|c|c|c|c|c|c|c|c|}
\hline Pairs of days & Mean & Mean dif. & Median & Median dif. & $\begin{array}{c}t \text {-value } \\
\text { (p-value) }\end{array}$ & $\begin{array}{c}\text { z-value } \\
\text { (p-value) }\end{array}$ & Conclusion \\
\hline h-5 to ho & $\begin{array}{c}-0.0004 \\
0.0042\end{array}$ & 0.0046 & $\begin{array}{c}-0.0040 \\
0.0020\end{array}$ & 0.0060 & $\begin{array}{l}-0.952 \\
(0.351)\end{array}$ & $\begin{array}{l}-1.258 \\
(\mathbf{0 . 2 0 9 )}\end{array}$ & No difference of AR \\
\hline $\mathrm{h}-4$ to ho & $\begin{array}{c}-0.0037 \\
0.0042\end{array}$ & 0.0079 & $\begin{array}{c}-0.0070 \\
0.0020\end{array}$ & 0.0090 & $\begin{array}{l}-1.716 \\
(0.099)\end{array}$ & $\begin{array}{c}-1.575 \\
(\mathbf{0 . 0 7 8})\end{array}$ & There is difference of $A R$ \\
\hline h-3 to ho & $\begin{array}{l}0.0010 \\
0.0042\end{array}$ & 0.0032 & $\begin{array}{c}-0.0020 \\
0.0020\end{array}$ & 0.0040 & $\begin{array}{l}-0.603 \\
(0.552)\end{array}$ & $\begin{array}{l}-0.929 \\
\mathbf{( 0 . 3 5 3 )}\end{array}$ & No difference of AR \\
\hline $\mathrm{h}-2$ to h0 & $\begin{array}{l}0.0086 \\
0.0042\end{array}$ & -0.0044 & $\begin{array}{l}0.0060 \\
0.0020\end{array}$ & -0.0040 & $1.143(0.264)$ & $\begin{array}{c}0.175 \\
(\mathbf{0 . 8 6 1 )}\end{array}$ & No difference of AR \\
\hline $\mathrm{h}-1$ to h0 & $\begin{array}{l}0.0107 \\
0.0042\end{array}$ & -0.0065 & $\begin{array}{l}0.0005 \\
0.0020\end{array}$ & 0.0015 & $1.176(0.251)$ & $\begin{array}{c}0.390 \\
(\mathbf{0 . 6 9 6})\end{array}$ & No difference of AR \\
\hline h0 to $h+1$ & $\begin{array}{c}0.0042 \\
-0.0077\end{array}$ & -0.0119 & $\begin{array}{c}0.0020 \\
-0.0020\end{array}$ & -0.0220 & $\begin{array}{l}-1.583 \\
(0.126)\end{array}$ & $\begin{array}{c}-1.887 \\
\left(0.059^{*}\right)\end{array}$ & There is difference of $A R$ \\
\hline h0 to $h+2$ & $\begin{array}{c}0.0042 \\
-0.0044\end{array}$ & -0.0086 & $\begin{array}{c}0.0020 \\
-0.0010\end{array}$ & -0.0030 & $\begin{array}{l}-1.814 \\
(0.082)\end{array}$ & $\begin{array}{l}-1.845 \\
\left(0.065^{*}\right)\end{array}$ & There is difference of $A R$ \\
\hline ho to $h+3$ & $\begin{array}{l}0.0042 \\
0.0267\end{array}$ & 0.0225 & $\begin{array}{l}0.0020 \\
0.0100\end{array}$ & 0.0080 & $1.482(0.151)$ & $\begin{array}{l}-0.958 \\
(\mathbf{0 . 3 3 8 )}\end{array}$ & No difference of AR \\
\hline h0 to $h+4$ & $\begin{array}{l}0.0042 \\
0.0027\end{array}$ & -0.0015 & $\begin{array}{l}0.0020 \\
0.0020\end{array}$ & 0.0000 & $\begin{array}{l}-0.275 \\
(0.786)\end{array}$ & $\begin{array}{c}0.000 \\
(\mathbf{1 . 0 0 0})\end{array}$ & No difference of AR \\
\hline ho to $h+5$ & $\begin{array}{c}0.0042 \\
-0.0029\end{array}$ & -0.0071 & $\begin{array}{c}0.0020 \\
-0.0030\end{array}$ & -0.0050 & $\begin{array}{l}-1.671 \\
(0.108)\end{array}$ & $\begin{array}{l}-1.501 \\
\mathbf{( 0 . 1 3 3 )}\end{array}$ & No difference of AR \\
\hline Before against after & $\begin{array}{l}0.0032 \\
0.0023\end{array}$ & -0.0009 & $\begin{array}{l}0.0020 \\
0.0007\end{array}$ & -0.0013 & $0.258(0.798)$ & $\begin{array}{l}-0.578 \\
(\mathbf{0 . 5 6 3 )}\end{array}$ & No difference of AR \\
\hline
\end{tabular}

Note: ${ }^{*}$ significant at $10 \%$. Figures in bold show that hypothesis testing is based on data distribution patterns. AR is abnormal returns. 
Table 7. Summary of third hypothesis testing results

\begin{tabular}{l|c|c|c|c}
\hline \multicolumn{1}{c}{ Period } & Mean (median) & Mean (median) difference & $\begin{array}{c}\boldsymbol{t} \text {-stat } \\
(\boldsymbol{p} \text {-value) }\end{array}$ & $\begin{array}{c}\text { z-stat } \\
(\boldsymbol{p} \text {-value) }\end{array}$ \\
\hline TVA before & $0.0122 \mathbf{( 0 . 0 0 6 1 )}$ & $\begin{array}{c}0.0036 \\
\mathbf{( - 0 . 0 0 0 8 )}\end{array}$ & $-0.884(0.386)$ & -0.121 (0.904) \\
\hline TVA after & $0.0158 \mathbf{( 0 . 0 0 5 3 )}$ & No difference of TVA \\
\hline
\end{tabular}

Note: Figures in bold = hypothesis testing based on data distribution patterns .

decreased by $1.19 \%(p<10 \%)$ and $0.86 \%(p<10 \%)$, respectively. This means that on two days after the announcement as host, namely $\mathrm{h}+1$ and $\mathrm{h}+2$, there are significant abnormal returns differences.

On the days before the announcement, namely $\mathrm{h}-5, \mathrm{~h}-3, \mathrm{~h}-2$, and $\mathrm{h}-1$, and on the days announcement namely, $h+3, h+4$, and $h+5$, changes in the median and the mean fluctuate, and there are no significant abnormal returns differences. That is, the abnormal returns on $\mathrm{h}-5, \mathrm{~h}-3, \mathrm{~h}-2, \mathrm{~h}-1, \mathrm{~h}+3$, $\mathrm{h}+4$, and $\mathrm{h}+5$ announcements as the host of XVIII Asian games are not different.

Based on the earlier description, it can be concluded that there is a significant difference in abnormal returns on the day before the announcement, namely on $\mathrm{h}-4$, and there is a significant difference in abnormal returns on the days after the announcement, namely $\mathrm{h}+1$ and $\mathrm{h}+2$. However, testing of other days did not show any significant differences. This means that the majority of the second hypothesis tests show that the second alternative hypothesis ( $\mathrm{Ha} 2)$ is rejected, i.e., there is no significant difference in the average abnormal returns before and after the announcement of the host of the XVIII Asian Games.

The third hypothesis relates to finding the difference in TVA before and after the announcement of the host of the XVIII Asian Games. Table 7 presents a summary of the third hypothesis testing results.

Table 7 shows the median values before and after the announcement as host of the XVIII Asian Games. The median value after the announcement has decreased by $0.08 \%$ from the median value before the announcement. The average TVA after the announcement increased by $0.36 \%$ from that before the announcement. The third alternative hypothesis, which states that there is a significant difference of the trading volume activity before and after the announcement of the host of the XVIII
Asian Games, was rejected. Wilcoxon paired sample test results indicate that there is no significant difference.

\section{DISCUSSION}

The first hypothesis of the study is related to testing whether there are significant abnormal returns around the event. It finds that there are significant abnormal returns on two days before the announcement (days $\mathrm{h}-4$ and $\mathrm{h}-2$ ) and two days after the announcement (days $\mathrm{h}+3$ and $\mathrm{h}+5$ ). Given only four days out of 11 days, one concludes that there is insufficient evidence to assert that there are significant abnornal returns around the event.

The results of the second hypothesis testing show that on the days before and after the announcement, significant abnormal returns difference was found on $\mathrm{h}-4$ to h0, h0 to $\mathrm{h}+1$, and $\mathrm{h} 0$ to $\mathrm{h}+2$, thus, only three pairs of days where the abnormal returns are different. Even if looking at the test between five days before and five days after, the result shows no significant difference. Thus, one concludes that there is insufficient evidence to accept the second hypothesis.

The results of this study indicate that there are no significant abnormal returns and there are no significant abnormal returns differences on the days around the announcement. That is, capital market participants who carry out trading activities and investment activities do not obtain the returns above normal returns and indicate that the abnormal returns obtained before and after the announcement are not much different. Investors are not affected by the existence of information from outside the company and prefer to consider the share prices from the fundamental side of the company. Investors may also consider that the announcement of the host of the XVIII Asian Games does not yet have the information content that the information is im- 
portant to influence the stock prices, so that no investors receive the abnormal returns around the announcement date.

The results of this study are in line the concept of an efficient market, which says that it is impossible to earn continuous abnormal returns using the available information. The results of this study are not in line with Spais and Fillis (2006), Scholtens and Peenstra (2009) and Benkraiem et al. (2009) who found that sport events generate the abnormal returns around the event. However, the results of this study are in line with the findings of Asteriou et al. (2013) who found only a slight impact of significant price changes due to an event. Dick and Wang (2010) also found insignificant abnormal returns at the winter Olympic Games in Europe.

The results of the third hypothesis testing show that the mean (increase) and median (decrease) trading volume activity before and after the announcement has changed, but the difference is insignificant. Trading volume activity is useful to see the existing information content by looking at the comparison of the number of shares traded with the shares outstanding at the time. The appointment of Indonesia as the host of Asian Games did not significantly increase the trading activity. In other words, the event is perceived to be an ordinary event. This finding is in line with the resuts of tests on possible abnormal returns.

On the days around the announcement date, supply and demand for shares remain stable as usual, making trading volume activity no different before and after the announcement. The results of this study are not in line with Spais and Filis (2006), Benkraiem et al. (2009), and Scholtens and Peenstra (2009) who found significant trade volume changes around sport events.

There are several limitations of this study. First, the sample in this study was 47 companies in the infrastructure, utilities and transportation sectors from July 2014 till August 2014, but only 25 companies were selected that fulfilled the sample criteria so that they could not reflect the overall shares of the infrastructure, utilities and transportation sectors. Second, the observation period in this study coincides with the month of Ramadan and the Eid al-Fitr holiday, so the market may be affected by these long holidays. One did not isolate these holidays' effect. Third, this study only uses the market-adjusted model to estimate the expected returns. There are several models for estimating the expected returns, for example, the market model and the mean adjusted model.

\section{CONCLUSION}

This study aims to analyze the existence of abnormal returns, differences in abnormal returns, and differences in trading volume activity before and after the announcement as the host of XVIII Asian Games in the infrastructure, utilities, and transportation sectors companies listed on the Indonesia Stock Exchange. There are three conclusions. First, there are no significant abnormal returns on the shares of the infrastructure, utilities, and transportation sectors companies before and after the announcement. Second, there is no significant difference in abnormal returns in the shares of the companies in infrastructure, utilities, and transportation sectors before and after the announcement. Third, there is no significant difference in trading volume activity in the shares of the companies in infrastructure, utilities, and transportation sectors before and after the announcement.

Referring to the conclusions and limitations of the research, some suggestions can be made. First, researchers are advised to conduct the studies in other sectors or many sectors so that they can describe the overall market situation. Second, researchers are further advised to examine the sport events that are not close to other events that are likely to interfere with the study. Third, researchers are also suggested to be able to estimate the abnormal returns based on other models, such as the mean adjusted model and the market model. 


\section{AUTHOR CONTRIBUTIONS}

Conceptualization: Andreas.

Data curation: Andreas, Tatang Ary Gumanti, Uliya Nurjannah, Intan Nurul Awwaliyah.

Formal Analysis: Andreas, Tatang Ary Gumanti, Uliya Nurjannah, Intan Nurul Awwaliyah.

Funding acquisition: Andreas.

Investigation: Andreas, Tatang Ary Gumanti.

Methodology: Andreas, Tatang Ary Gumanti, Uliya Nurjannah, Intan Nurul Awwaliyah.

Project administration: Andreas, Uliya Nurjannah, Intan Nurul Awwaliyah.

Supervision: Andreas, Tatang Ary Gumanti.

Visualization: Andreas, Tatang Ary Gumanti, Uliya Nurjannah, Intan Nurul Awwaliyah.

Writing - original draft: Andreas.

Writing - review \& editing: Andreas, Tatang Ary Gumanti.

\section{REFERENCES}

1. Abuzayed, B. (2013). Sport and emerging capital markets: Market reaction to the 2022 World Cup announcement. International Journal of Islamic and Middle Eastern Finance and Management, 6(2), 122-141. https://doi. org/10.1108/17538391311329824

2. Asteriou, D., Samitas, A., \& Kenourgios, D. (2013). The London 2012 Olympic games announcement and its effect on the London Stock Exchange. Journal of Economics Studies, 40(2), 203-221. https://doi. org/10.1108/01443581311283673

3. Benkraiem, R., Louhichi, W., \& Marques, P. (2009). Market reaction to sporting results: The case of European listed football clubs. Management Decision, 47(1), 100-109. https://doi. org/10.1108/00251740910929722

4. Birgham, E. F., \& Ehrhard, M. C. (2011). Financial Management Theory and Practice (13th ed.). Melbourne: Cengage Learning.

5. Bodie, Z., Kane, A., \& Marcus, A. (2018). Investment (11th ed.). New York: McGraw-Hill.

6. Dick, C. D., \& Wang, Q. (2010). The economic impact of the Olympic games: Evidence from stock market. Applied Economics Letters, 17(9), 861-864. https://doi. org/10.1080/13504850802552291

7. Fama, E. F. (1970). Efficient capital markets: A review of theory and empirical work. Journal of Finance, 25(2), 383-417. https:// doi.org/10.1111/j.1540-6261.1970. tb00518.x
8. Fama, E. F. (1991). Efficient capital markets: II. Journal of Finance, 46(5), 1575-1617. https://doi. org/10.1111/j.1540-6261.1991. tb04636.x

9. Gumanti, T. A. (2011). Manajemen Investasi: Konsep, Teori, dan Aplikasi. Jakarta: Mitra Wacana Media.

10. Gumanti, T. A., Savitri, E., Nisa, N. W., \& Utami, E. S. (2018). Event study on the crash of airasia plane: A study on travel and leisure companies listed at Malaysian Stock Market. Jurnal Akuntansi dan Keuangan, 20(1), 20-26. https://doi. org/10.9744/jak.20.1.20-26

11. Hartono, M. H. (2010). Teori Portofolio dan Analisis Investasi. Yogyakarta: BPFE-UGM.

12. Homar, A. (2015). The effect of airplane crashes on stock performance of US. airlines and airplane manufacturers between 1983 and 2013 (Thesis). Ljubljana: Faculty of Economics. University of Ljubljana.

13. Konchitchki, Y., \& O'Leary, D. E. (2011). Event study methodologies in information systems research. International Journal of Accounting Information Systems, 12(2), 99-115. https://doi.org/10.1016/j.accinf.2011.01.002

14. Mirman, M., \& Sharma, R. (2010). Stock market reaction to Olympic Games announcement. Applied Economic Letters, 17(5), 463-466. https://doi. org/10.1080/13504850801964349

15. Peterson, P. P. (1989). Event studies: A review of issues and methodology.
Quarterly Journal of Business and Economics, 28(3), 36-66. https:// www.jstor.org/stable/40472954

16. Purnasari, L. H., Siregar, H., \& Maulana, N. A. (2015). Impacts of Indonesia raw minerals export ban on abnormal return and trading volume: An event study on stocks of metals and minerals mining subsector in IDX. Asian Journal of Business and Management, 3(6), 2321-2802.

17. Scholtens, P., \& Peenstra, W. (2009). Scoring on the stock exchange? The effect of football matches on stock market returns: An event study. Applied Economics Letters, 41(25), 3231-3237. https://doi. org/10.1080/00036840701721406

18. Schweitzer, R. (1989, July). How do stock return react to special events? Business Review, 17-29.

19. Sorescu, A., Warren, N. L., \& Ertekin, L. (2017). Event study methodology in the marketing literature: An overview. Journal of the Academic Marketing Science, 45(2), 186-207. https://doi. org/10.1007/s11747-017-0516-y

20. Spais, G. S., \& Filis, G. N. (2006). Stock market reaction on Olympic sponsorship announcement using event-study method. Journal of Global Academy of Marketing Science, 16(2), 95-108. https://doi.or g/10.1080/12297119.2006.9707366

21. Suryanto. (2015). Analysis of abnormal return before and after the announcement of investment grade Indonesia. International Journal of Business and Management Review, 3(1), 11-23. 